\title{
PECULIARITIES OF STATE REGULATION OF SCIENTIFIC RESEARCHES IN THE AGRICULTURAL SPHERE IN THE UKRAINIAN SOVIET SOCIALIST REPUBLIC DURING THE PERIOD OF RECONSTRUCTION (1943-1945)
}

\section{Olena Korzun}

\section{INTRODUCTION}

Owing to military actions on the territory of The Ukrainian SSR (the Ukraine) in the World War II, great damage was caused to agricultural research institutions and farms: most of the establishments, stations, and fields were destroyed, and many of them were ruined and robbed ${ }^{1}$. Some research institutions were evacuated to the remote rear soon after the war outbreak, where they continued to carry out scientific experiments. The temporary occupation of the Ukraine's territory by the Nazi invaders destroyed the Republic's agriculture and completely disorganized the existing system of agricultural research. After scientists returned to the liberated territories of the Ukrainian SSR, they began solving organizational issues along with scientific tasks ${ }^{2}$. Excessive work of scientists, who managed to eliminate negative consequences of Nazi's impact on the Ukrainian SSR by restoring industry research and the reconstruction of agricultural production within the shortest span of time, ensured the further effective development of agriculture in the country.

Therefore, measuring the contribution of agricultural research institutions during the reconstruction period and production process of the Ukrainian SSR within 1943-1945 can be considered as a powerful basis for the impartial display of the past and effective planning of

${ }^{1}$ Verhunov, V. A. (2012). Sil's 'kohospodars'ka doslidna sprava v Ukrayini vid zarodzhennya do akademichnoho isnuvannya: orhanizatsiynyy aspekt. [Agricultural research in Ukraine from birth to academic existence: an organizational aspect.] Kyyiv: Ahrarna nauka. P. 58.

${ }^{2}$ Verhunov, V. A. \& Khyzhnyak, V. P. (2004). Ukrayins'ki naukovo-doslidni sil's'kohospodars'ki zaklady $\mathrm{v}$ roky Velykoyi Vitchyznyanoyi viyny. [Ukrainian agricultural research institutions during the Great Patriotic War.] Istorychni zapysky: zbirnyk naukovykh prats'. 1. P. 20. 
perspective agricultural production in Ukraine. It is important to clarify the peculiarities of state regulation of industrial scientific researches in accordance with different areas of agricultural production in the Ukrainian SSR. In particular, they embrace determining scientific provision of spheres such as land, crop, fruit farming, viticulture and winemaking; defining the ways of reconstruction of scientific researches in the sphere of breeding and seed crops; specifying the ways of reproduction of scientific and organizational process in agronomic amelioration and mechanization of agriculture, as well as scientific basis for reconstructive processes in technical husbandry.

\section{The peculiarities of administering agricultural researches in Ukrainian SSR during the period of reconstruction}

During 1941-1945, industrial research institutions suffered great damage - most of the institutions, stations, and fields were destroyed, others were extremely ruined and robbed. Soon after the start of military actions, some research institutions were evacuated to the remote rear, where they continued to carry out scientific researches. After the return of institutions, scientific stations, and fields to the liberated territories of the Ukrainian SSR, scientists began solving organizational issues along with scientific tasks. Within 1943-1945 excessive free work of scientists, who managed to eliminate negative consequences of Nazi impact on the Ukrainian SSR by means of restoring industry research and the reconstruction of agricultural production within the shortest period, ensured the further effective development of industrial science and practice.

Even before World War II, Ukrainian farmers boasted of the functionally extensive network of agricultural research institutions, which consisted of 15 institutes, 34 research stations, 16 research fields, and 62 experimental stations, which were under different subordination $^{3}$. Particularly, they subordinated to the People's Commissariat of Agriculture and the People's Commissariat of the food

3 Verhunov, V. A. \& Khyzhnyak, V. P. (2004). Ukrayins'ki naukovo-doslidni sil's'kohospodars'ki zaklady V roky Velykoyi Vitchyznyanoyi viyny. [Ukrainian agricultural research institutions during the Great Patriotic War.] Istorychni zapysky: zbirnyk naukovykh prats'. 1. P. 20. 
industry in Ukraine, and the People's Commissariat of Agriculture in the Ukrainian SSR. Besides, several agricultural training departments functioned at universities and institutions of the People's Commissariat of Education. The issues concerning the scientific provision of agricultural production were also solved by scholars of the Agriculture Department, Academy of Sciences of the Ukrainian SSR.

Before the Nazi occupation, the work of Ukrainian SSR research institutions' was systematized according to the main areas: agriculture and crop production, breeding and seed production, agronomic amelioration, mechanization and electrification of agriculture, fruit growing, viticulture and winemaking, animal husbandry, etc. This network was presented by well-organized research institutions, which were equipped with laboratories, experimental centers, animal farms, collection nurseries, forest and fruit plantations, etc. At the beginning of 1941, the overall number of scientific staff in institutes, experimental stations and fields were approximately 520 senior researchers with a budget of more than 17 million rubles ${ }^{4}$. The agricultural scientists achieved considerable global success, particularly concerning the effectiveness of agricultural actions, fertilizers, melioration, actions connected with pest control and crops' diseases. Together with achievements that agricultural science made in the early 1940s, there were also shortcomings, which included the imperfection of its organization and management system. Research institutions were separated and had no proper unified scientific and methodological center, which would manage and direct all the work of the network according to the appropriate scientific plan.

As the Ukrainian territories were liberated from the Nazi invaders, the Central Committee of Communist Party and the Council of People's Commissars of the Ukrainian SSR adopted resolutions on restoring the work of the Ukrainian SSR research institutions. The first document was the resolution of the Council of People's Commissars of the Ukrainian SSR № 545 “On the restoration of the work of agricultural

${ }^{4}$ Verhunov, V. A. (red.). (2012). Sil's'ke hospodarstvo URSR ta yoho naukove zabezpechennya u 1940-1946 rokakh: zb. dok. i materialiv. [USSR agriculture and its scientific support in 1940-1946: coll. dock. and materials.] NAAN, DNS·HB, TSDAVO Ukrayiny. Kyyiv: Nilan-LTD. P. 34-36. 
research institutions of the Ukrainian SSR", dated December 13, $1943^{5}$. In accordance with this resolution, the work of the following institutions was reconstructed: the Central scientific agricultural library and five research institutes (The Ukrainian research Institute of socialist agriculture (Kharkiv), The Ukrainian research Institute of agricultural mechanization, The Ukrainian research Institute of animal husbandry, The Ukrainian research Institute of experimental veterinary medicine, The Ukrainian branch of the Institute of fodder), eight research stations (Krasnograd breeding and experimental station, Experimental centres of the Ukrainian Research Institute of agricultural mechanization, the Ukrainian research Institute of animal husbandry, the Ukrainian research Institute of experimental veterinary medicine, Chernihiv animal husbandry research station, Ukrainian poultry research station, Kharkiv and Stalin vegetable and potato stations).

The following resolutions of the Council of People's Commissars of the Ukrainian SSR on the reconstruction of the Ukrainian scientific and research activities, approved in 1944 (№ 232 of March 18, № 495 of May 15, № 678 of June 17), restored the activities of 59 research institutions $^{6}$. To them belong 1 library, 10 scientific and research institutes, 26 research stations, 15 research fields, 7 experimental stations. In the Western regions of the Ukrainian SSR, it was planned to organize new research institutions of national importance. In particular, the work of Lviv research station of field breeding and experimental fields in Drohobych and Stanislavsky areas of the Ukrainian SSR started for the purpose of scientific provision of Lviv region agriculture based on the resolution of the Ukrainian SSR Council of People's Commissars № 36-10 of March 25, 1945 on the organization of research institutions in the Western areas of the Ukrainian SSR in connection with the resolution of the Council of People's Commissars of the Ukrainian SSR № 775 of May 12, 1945. In scientific and

${ }^{5}$ Verhunov, V. A. (red.). (2012). Sil's'ke hospodarstvo URSR ta yoho naukove zabezpechennya u 1940-1946 rokakh: zb. dok. i materialiv. [USSR agriculture and its scientific support in 1940-1946: coll. dock. and materials.] NAAN, DNS·HB, TSDAVO Ukrayiny. Kyyiv: Nilan-LTD. P. 19.

${ }^{6}$ Verhunov, V. A. (red.). (2012). Sil's'ke hospodarstvo URSR ta yoho naukove zabezpechennya u 1940-1946 rokakh: zb. dok. i materialiv. [USSR agriculture and its scientific support in 1940-1946: coll. dock. and materials.] NAAN, DNS·HB, TSDAVO Ukrayiny. Kyyiv: Nilan-LTD. P. 20. 
research establishments, the departments such as agricultural technology and chemistry, vegetable breeding, breeding and seed, fodder production, plant protection, economics and organization of agriculture were organized to conduct complex, scientific and research experiments in the field of agriculture. Besides, the laboratory of agricultural chemistry, soil microbiology, and agricultural agrometeorology was created. However, during the occupation, a large number of experimental stations were destroyed. In particular, in 1941 there were 42 establishments, and in 1944 there were only 7. Nevertheless, on August 1, 1944, 94\% of research institutes, stations and fields were restored, in comparison with 1941.

So, in 1944 the network of the Ukrainian SSR scientific and research institutions was systematized in the following directions: agriculture and crop production, husbandry and seed production, agronomic melioration, mechanization and electrification of agriculture, fruit growing, viticulture and winemaking, animal husbandry, etc. The following institutions focused on the agriculture and crop production, breeding and seed production: 1) The Ukrainian research Institute of socialist agriculture (Kyiv) with a network of experimental stations, fields and research points (Polissia scientific and research station of field husbandry, The Kazarovychi scientific and research station of grassland culture, Sarny scientific and research station of the swamp reclamation, The Chernivtsi scientific and research station of field husbandry, Lanovtsy scientific and research breeding station, Kyiv, Kharkiv, Stalin, Odessa breeding vegetable and potato stations and Skvyra experimental breeding plot, Korosten, Chartoriy and Gradizh experimental plots, Buchan and Sviatoshyn experimental stations); 2) The Ukrainian scientific and research Institute of socialist agriculture (Kharkiv) with a network of experimental stations, fields and research centres (Chervonograd breeding and experimental station, Valkiv experimental plot); 3) Ukrainian scientific and research Institute of grain farming (Dnipropetrovsk) with a network of experimental stations, fields and research centres (Erastiv, Synelnikiv, Luxemburg, Genichesk, Starobilske experimental fields, Olexandrovsk scientific and research watermelon experimental center, Odessa scientific and research station of crop breeding, Zherebkiv scientific and research station of crop 
breeding, Ukrainian scientific and research station of oil crops, Ukrainian scientific and research station of rice growing) ${ }^{7}$.

According to the sphere of agromelioration, in the following instituitions carried out researches: 1) Ukrainian scientific and research Institute of agro-forestry-melioration (Kharkiv) with a network of research stations and experimental centres (Tsyurupinsk scientific and research station of sands reclamation of the Lower Dnieper (Tsyurupinsk), Mariupol and Volodymyr agro-forestry-melioration scientific and research stations, Guerrilla agroforestry-melioration experimental station, Prydesnyansk experimental station of soil erosion); 2) Ukrainian scientific and research Institute of water engineering and melioration (Kyiv) with a network of experimental stations and fields (Bril scientific and research irrigation station, Sumy, Panfilov, Borovsk and Kamenske on the Dnieper experimental fields). Mechanization and electrification of agriculture was under scrutiny in: 1) Ukrainian scientific and research Institute of mechanization of agriculture (Kyiv) with subordinate research stations: Kharkiv scientific and research station of mechanization (Kharkiv), Akymivka scientific and research station of mechanization (Akimivka, Zaporizhia region) ${ }^{8}$.

In the direction of fruit growing, viticulture and winemaking research was carried out by: 1) Ukrainian research Institute of fruit growing (Kitaevo, m. Kiev) with subordinate experimental stations and reference points (Mlievskaya, Melitopol research station of fruit growing, Krasnokutsky, Yamsky and Vozdvizhensky extended reference points); 2) Ukrainian research Institute of viticulture and winemaking (Odessa). In the direction of animal husbandry worked: 1) Ukrainian research Institute of animal husbandry (n. Kharkiv) with subordinate research stations (Chernihiv research station of animal husbandry, Chernihiv research station of poultry (Borki, Kharkiv region, Ukrainian research station of beekeeping (Merefa, Kharkiv

7 (1944). Dodatok do Nakazu № 1147 NKZS URSR pro vidnovlennya ta stan roboty naukovo-doslidnykh ustanov za 1944 r. [Addendum to the Order \# 1147 of the NKVD of the USSR on the restoration and state of operation of research institutions for 1944] TSDAVO Ukrayiny. F. 27. Op. 17. Spr. 1053. Ark. 292-293.

${ }^{8}$ Verhunov, V. A. (red.). (2012). Sil's'ke hospodarstvo URSR ta yoho naukove zabezpechennya u 1940-1946 rokakh: zb. dok. i materialiv. [USSR agriculture and its scientific support in 1940-1946: coll. dock. and materials.] NAAN, DNS·HB, TSDAVO Ukrayiny. Kyyiv: Nilan-LTD. P. 22. 
region), Ukrainian research station of fish farming (Sultanivka, Kyiv region); 2) Ukrainian research Institute of experimental veterinary medicine (Kharkiv) ${ }^{9}$.

The following institutions conducted the researches in the sphere of fruit farming, viticulture and winemaking: 1) Ukrainian scientific and research Institute of fruit farming (Kitaevo, Kyiv) with subordinate research stations and experimental centers (Mliiv, Melitopol scientific and research station of fruit growing, Krasnokutsk, Yam and Vozdvyzhensk extended experimental centers); 2) Ukrainian scientific and research Institute of viticulture and winemaking (Odessa). The sphere of animal husbandry was under scrutiny in: 1) Ukrainian scientific and research Institute of animal husbandry (Kharkiv) with subordinate research stations (Chernihiv scientific and research station of animal husbandry, Chernihiv research station of poultry farming (Borky, Kharkiv region, The Ukrainian scientific and research station for apiculture (Merefa, Kharkiv region), The Ukrainian scientific and research station for fishery (Sultanivka, Kyiv region); 2) The Ukrainian scientific and research Institute of experimental veterinary medicine (Kharkiv) .

During World War II, the staff members of the research institutions were affected deeply. In August 1, 1944, there were only 184 senior researchers in the restored network, which made up 35\% in comparison with 1941. They included 19 chief executives and professors, 66 candidates of agricultural sciences and 85 people with a scientific degree. August, 1, 1944, there were professional staff members such as chief executive officers, their deputies of scientific work and chief accountants. However, the average quantity of staff members reached $62 \%$ in the Ukrainian scientific and research institutions. It was planned to meet the scientific staff members needs through extending full-time and part-time postgraduate studies, as well as upgrading current employees' skills. By the end of 1944, it was intended to begin the training program of 70 scientific staff members, among which 55 were be extramural students.

9 (1944). Dodatok do Nakazu № 1147 NKZS URSR pro vidnovlennya ta stan roboty naukovo-doslidnykh ustanov za 1944 r. [Addendum to the Order № 1147 of the NKVD of the USSR on the restoration and state of operation of research institutions for 1944] TSDAVO Ukrayiny. F. 27. Op. 17. Spr. 1053. Ark. 293. 
The department of Ukrainian scientific and research institutions, as the highest scientific institution and at the same time scientific, methodical and coordination center of agricultural science in the country, provided the management of agricultural research in the period of reconstruction. The formation of the Ukrainian Republican Scientific Council, as a body that developed the main recommendations for solving important tasks within scientific, methodological and organizational sphere was started in order to strengthen the management of the agricultural research field. The aforementioned Scientific Council was to coordinate scientific and academic plans of all scientific and research institutions despite their subordination, in order to provide the unified methodical direction of the scientific work. There was also a perspective in adjusting academic forms of management in accordance with principles of the Academy of Sciences of the Ukrainian SSR.

In 1944, scientific and methodological plan of scientific and research institutions of the Ukrainian SSR network mainly duplicated the theme of the pre-war period. It is quite understandable, since the main problems solved in the early 1940s in the sphere of agricultural development, remained significantly relevant both in the wartime and during the period of reconstruction. The main topics, developed in the scientific and research institutions, were long-term ones. Annually the scientific and research institutions, stations and fields, solved problems connected with the requirements of socialist agricultural production of a certain span of time. Thus, such tasks as increasing soil fertility, crop yields and improving product quality, the creation of new varieties of grain and industrial crops, the introduction of improved agricultural techniques, remained relevant. The defining criteria in solving these problems were the basic requirements to production set by operational organizations of collective and state farms before science. The main requirements to the production, which were stated by collective and state farms, appeared to be defining criteria during solving these problems ${ }^{10}$. While planning and carrying out scientific research, special attention was paid to the main resolutions of People's Commissars of

10 Kalachykov, O. T. (1945). Dosyahnennya y zavdannya naukovo-doslidnykh zakladiv Narkomzemu Ukrayiny .[and tasks of the National Research Commissions of Ukraine.] Sil's 'ke hospodarstvo Ukrayiny. 1. P. 60. 
the Ukrainian SSR in 1944: "On improving seed production of grain crops", "On improving seed production of potatoes", "On improving breeding and seed production of vegetable and melon crops", "On the development of animal husbandry", "On the development of fruit growing", etc.

The scientific and academic plan of conducting researches by the Ukrainian SSR scientific and research institutions, approved for 1944-1945, comprised 110 topics, which united 7-8 key tasks, and were divided according to the main groups: land husbandry embraced 42 topics, mechanization - 9 topics, animal husbandry and experimental veterinary - 19 topics; fruit farming and breeding of potatoes -26 topics; agronomic melioration -14 topics.

In particular, it was necessary to develop methods and techniques of intensive herd restoration of working and productive cattle of all kinds in the cattle breeding. At the same time, it was also significant to improve breed structure; to apply the main achievements in eliminating epizootics and other diseases of agricultural animals and poultry, to destroy the nidi of diseases left after fascist occupation; to elaborate the system of actions for apiculture and fishery development in collective farms ${ }^{11}$.

It was expected to explore simplified but highly productive structures of sowing, harvesting and winnowing machines; develop the system of economic usage of fuel and lubricating materials; prepare technical characteristics of agricultural machines and engines samples for their effective usage; broadly implement positive results of testing agricultural machines and household production devices. Restoration of destroyed forest protective hedges, as well as pond farms and irrigated agriculture was introduced in the sphere of agricultural melioration.

In agriculture and crop production, fruit farming, viticulture and winemaking, it was necessary to develop a set of main agrotechnical measures in order to restore beet farming, eliminate the negative consequences of violations of crop rotations, to make efforts to restore the grain economy, to reconstruct elite and reproductive seeds of

11 Verhunov, V. A. (red.). (2012). Sil's'ke hospodarstvo URSR ta yoho naukove zabezpechennya u 1940-1946 rokakh: zb. dok. i materialiv. [USSR agriculture and its scientific support in 1940-1946: coll. dock. and materials.] NAAN, DNS·HB, TSDAVO Ukrayiny. Kyyiv: Nilan-LTD. P. 27. 
high-yielding varieties of grains, vegetables and herbs; to promote the production of high yields of potatoes and vegetables. The exploration of effective methods of growing high yield-rubber, in particular Koksagiz, as well as oilseeds and yarn crops as an important strategic agricultural raw material; agricultural rice growing techniques for collective farms was necessary. This complex also included various methods of using artificial fertilizer, various composts, green fertilizers and the most intensive using of substances, which contain nitrogenfixing bacteria (nitrogen backterin) and nodule bacteria (nitragin) ${ }^{12}$. Another task was to develop and apply agricultural production and storage methods of biologically bound nitrogen as an additive to nitrogen fertilizers; to improve the restoration of fruit plantations, berries and vineyards in the Ukrainian SSR; to develop a system for combating potato cancer, viral diseases of industrial crops, in particular tobacco and rubber plants.

Suffice it to mention the productive work of the Academy of Sciences of the Ukrainian SSR scientists, aimed at the needs of agriculture. For that purpose at the beginning of 1945, the solution to the problem of creation the network of institutions in its structure aimed at solving agricultural problems. April, 20, 1945, the Presidency of the Academy of sciences of the Ukrainian SSR approved of the decree with regard to creation the Commission on organization the Department of Agricultural Sciences of the Ukrainian $\mathrm{SSR}^{13}$. The following distinguished scholars became its members: M. Gryshko, O. Dushechkin, associate member V. Starchenko (the Minister of agriculture of the Ukrainian SSR), P. Vlasiuk, P. Pogrebnyak, Ya. Roll, L. Rubenchik, full professor O. Markevich.

In the mid 1945, the Presidency of the Academy of Sciences of the Ukrainian SSR has considered the Commission's proposals on

${ }^{12}$ Verhunov, V. A. (red.). (2012). Sil's'ke hospodarstvo URSR ta yoho naukove zabezpechennya u 1940-1946 rokakh: zb. dok. i materialiv. [USSR agriculture and its scientific support in 1940-1946: coll. dock. and materials.] NAAN, DNS·HB, TSDAVO Ukrayiny. Kyyiv: Nilan-LTD. P 26.

${ }^{13}$ Zubets', M. V. (red.). (2008). Viddil sil's 'kohospodars'kykh nauk Natsional 'noyi akademiyi nauk Ukrayiny (1945-1956): zb. dok. $i$ materialiv. [Department of Agricultural Sciences of the National Academy of Sciences of Ukraine (1945-1956): Coll. dock. and materials.] UAAN, DNS·HB UAAN, NAN Ukrayiny, NBU im. V. I. Vernads'koho. Kyyiv: Ahrarna nauka. P. 21. 
formation of the Department of Agricultural Sciences of the following institutions:

1. The Institute of soil science (based on the Laboratory of soil science and the Department of soil Microbiology of the Institute of Microbiology).

2. The Institute of plant physiology and agrochemistry (based on the Department of plant physiology of the Institute of botany).

3. The Institute of entomology, parasitology and phytopathology (based on the departments of entomology and parasitology of the institute of zoology).

4. The Institute of genetics and selection (on the basis of departments of genetics and selection of Institute of Zoology and selection).

5. The Institute of crop production (on the basis of the existing Institute of socialist agriculture of the Ukrainian SSR (Kharkiv).

6. The Institute of forestry (on the basis of the Department of ecology of the Botanical garden and experimental forestry).

7. The Institute of agricultural mechanics (based on the Laboratory of agricultural engineering and problems of agricultural mechanics).

Besides, the Commission requested the Presidency to involve the following academicians to the Department of agricultural Sciences of the Academy of Sciences of the Ukrainian SSR: T. Lysenko, A. Sapegin, V. Pospelov, O. Sokolovsky, M. Gryshko, O. Dushechkin, V. Yuriev; associate members: E. Zverezomb-Zubovskiy, P. Vlasyuk, P. Vasylenko, P. Pogrebniak, P. Sviridenko, Y. Modilevskiy, M. Popov. Moreover, another request was aimed at addressing the Council of People's Commissars of the Ukrainian SSR to conduct additional elections of full and associate members for different specialties: crop production, agrophysiology, agricultural mechanics, plant breeding, genetics, forestry (full members); soil science, crop production, agrochemistry, phytopathology, parasitology, plant breeding, animal breeding, technology and primary processing of agricultural products (associate members) ${ }^{14}$.

${ }^{14}$ Zubets', M. V. (red.). (2008). Viddil sil's 'kohospodars'kykh nauk Natsional'noyi akademiyi nauk Ukrayiny (1945-1956): zb. dok. $i$ materialiv. [Department of Agricultural Sciences of the National Academy of Sciences of Ukraine (1945-1956): Coll. dock. and materials.] UAAN, DNS·HB UAAN, NAN Ukrayiny, NBU im. V. I. Vernads'koho. Kyyiv: Ahrarna nauka. PP. 25-26. 
In August 24, 1945, the Presidency allowed to form the Department of agricultural Sciences and its institutions in the structure of the Academy of Sciences of the Ukrainian SSR. Those institutions included The Institute of physiology of agricultural plants and agrochemistry, The Institute of genetics and selection, The Institute of entomology and phytopathology, Institute of forestry. The newly formed department the laboratory of mechanical engineering and agricultural mechanics also included the Department of Technical Sciences and the laboratory of soil science with the Botanical garden ${ }^{15}$.

In October, 1945, the Council of People's Commissars of the Ukrainian SSR and the Central Committee of Communist Party adopted a resolution on the formation of the Department of Agricultural Sciences in the structure of the Ukrainian SSR Academy of Sciences with the purpose of creating a single governing body of agricultural science for the fundamental solution to the theoretical issues related to improving soil fertility, creation of new high-productive crops, development of an effective system of plant nutrition, as well as for solving problems of agricultural engineering and tractor industry. The aim of the Department of Agricultural Sciences of the Academy of Sciences of the Ukrainian SSR was to solve urgent theoretical problems in the agricultural science, which were not feasible for separate scientific and research institutions and experimental stations. Besides, another aim was to implement widely and efficiently the results of scientists theoretical developments in agricultural production. ${ }^{16}$

\section{The reconstruction of scientific and organizational process in the agriculture of the Ukrainian SSR}

During the German occupation, the national economy in all regions of the Ukrainian SSR underwent massive destruction. The population living in the zone of military operations was involved in

${ }^{15}$ Verhunov, V. A. (red.). (2012). Sil's'ke hospodarstvo URSR ta yoho naukove zabezpechennya u 1940-1946 rokakh: zb. dok. i materialiv. [USSR agriculture and its scientific support in 1940-1946: coll. dock. and materials.] NAAN, DNS·HB, TSDAVO Ukrayiny. Kyyiv: Nilan-LTD. P. 31.

16 (1948). Vazhneyshye reshenyya po sel'skomu khozyaystvu za 1938-1946 rr. [The most important decisions on agriculture for 1938-1946] Moskva: Sel'khozgyz. P. 29. 
hard slave work while the agricultural resources were drastically exploited $^{17}$. On the one hand, great damage was caused to the agriculture of the country by the predatory policy of the invaders and destructive measures during retreat; on the other hand, incorporation of agricultural resources for the military needs and evacuation of scientific and research institutions to the East ${ }^{18}$. The losses of the agricultural sector were significant: the mass destruction of long-term experiments in the experimental fields, stations and collective farms, as well as a significant reduction in acreage led to a rapid decline in crop yields ${ }^{19}$ and livestock in animal husbandry ${ }^{20}$. In general, of all the Soviet Union the Ukrainian SSR suffered the greatest damage, namely 285 billion rubles $^{21}$ or $42 \%{ }^{22}$.

17 Torzecki, R. (1993). Polacy I Ukraincy. Sprawa ukrainska w czasie II wojny swiatowej na terenie II Rzeczypospolitej.[Poles and Ukrainians. The Ukrainian case during World War II in the territory of the Second Polish Republic] Warszawa: Wydawnictwo naukowe PWN. P. 39.

18 Vlasenko, S. (2010). Naslidky nimets'koyi okupatsiyi dlya sil's'koho hospodarstva viys'kovoyi zony Ukrayiny (za dokumentamy derzhavnykh arkhiviv Ukrayiny). [Consequences of German occupation for agriculture of the military zone of Ukraine (according to documents of the state archives of Ukraine)] Kyyiv. P. 100.

19 (1945). Dopovidni zapysky i dovidky pro rezul'taty perevirky spivrobitnykamy NKZS URSR stanu tvarynnytstva v kolhospakh URSR (za oblastyamy) u 1945 r. [Additional notes and certificates on the results of the examination of the stock-raising of the livestock in the collective farms of the Ukrainian SSR (by oblasts) in 1945] TSDAVO Ukrayiny. F. R-27. Op. 17. Spr. 8886. Ark. 6.

20 (1945). Dopovid' Narkoma zemlerobstva URSR H.P. Butenka na Pershomu respublikans'komu zasidanni peredovykiv produktyvnoho tvarynnytstva i konyarstva kolhospiv URSR vid 24-27 hrudnya 1945 r. [Report of the People's Commissar of Agriculture of the Ukrainian SSR GP Butenko at the First Republican Meeting of the Leaders of Productive Livestock and Horse Breeding of the Collective Farms of the USSR from December 24-27, 1945.] TSDAVO Ukrayiny. F. R-27. Op. 17. Spr. 8882. Ark. 7.

21 Torzecki, R. (1994) Die Rolle der Zusammenarbeit mit der deutschen Besatzungsmacht in der Ukraine für deren Okkupationspolitik [The role of cooperation with the German representative power in Ukraine for its occupation policy] Europa unterm Hakenkreuz. Okkupation und Kollaboration 1938-1945, Achtbändige Dokumentenedition. [Europe under the swastika. Occupation and collaboration 1938 1945, eight-volume document edition] Bd. 1, Berlin/Heidelberg, P. 239-273.

${ }^{22}$ Ovsiyenko, A. M. (2010). Osoblyvosti finansovoyi systemy Ukrayins'koyi RSR u vidbudovchyy period (druha polovyna 40-kh - pochatok 50-kh rokiv XX st.). [Features of the financial system of the Ukrainian SSR in the reconstruction period (the second half of the 1940s - the beginning of the 1950s).] Kyyiv. P. 27. 
As a consequence of Soviet and German troops retreat and offensive fighting and bombing, 27910 collective farms, 872 state farms, 1300 machine and tractor stations were turned into ruins. In fact, the material and technical base of all branches of agricultural production of the Ukrainian SSR was completely destroyed: 56128 tractors, 24128 combines, 1187 different agricultural machines. After the liberation, one third of tractors remained in the agriculture of the country in comparison with pre-war level, the quantity of agricultural machines reduced 3 times, and the number of combine-harvesting machines became 5 times less. Retreating under the blows of the Soviet troops, the Nazis tried to take food and raw materials with them to the west. During the period of occupation, 4415 thousand tons of grain and flour, 1310 thousand tons of potatoes, vegetables and fruits, 458 tons of hay were shipped from the collective farms of the Ukrainian SSR to Germany ${ }^{23}$.

In general during 1941-1945, 1808 thousand houses were destroyed in the villages, 7594 thousand cattle heads were slaughtered and exported to Germany, 9333 thousand swine, 7317 thousand sheep and goats, 59297 thousand poultry, 3311 thousand horses; 17307 thousand tons of grain were either destroyed or exported. In the collective farms of the Ukrainian SSR, more than 230 thousand buildings were ruined, 18 million hectares of crops, 144 thousand hectares of gardens and vineyards were cut down as a result of military operations and following the instructions of both Soviet and German authorities ${ }^{24}$.

As for the animal husbandry, the destruction of the breeding business was extremely disastrous. At the beginning of 1940, the center of breeding cattle reproduction was formed and functioned successfully in the Ukrainian SSR, which both satisfied Republican needs and allowed to deliver breeding cattle to other areas and the republics of the USSR. In 1941, breeding cattle was raised by 13 state breeding nurseries and 687 breeding farms, pigs -4 state breeding nurseries and

${ }^{23}$ Verhunov, V. A. (red.). (2012). Sil's'ke hospodarstvo URSR ta yoho naukove zabezpechennya u 1940-1946 rokakh: zb. dok. i materialiv. [USSR agriculture and its scientific support in 1940-1946: coll. dock. and materials.] NAAN, DNS·HB, TSDAVO Ukrayiny. Kyyiv: Nilan-LTD. P. 9.

24 (1975). Ukraynskaya SSR v Velykoy Otechestvennoy voyne Sovetskoho Soyuza 1941-1945 rr. [The Ukrainian SSR in the Great Patriotic War of the Soviet Union 1941-1945.] V 3-kh t. T. 3. Kyev: Polytyzdat. P. 155-156. 
699 breeding farms, horses - 3 state breeding nurseries and 360 breeding farms, poultry - 257 breeding farms. There was also a network of breeding animal farms within collective farms. The significant amount of the breeding stock was lost during the evacuation in the first war months, and the rest was looted, slaughtered or taken by the Nazi invaders to Germany; as a result, at the time of the liberation of the Ukrainian SSR breeding stock was actually destroyed.

During the period of occupation, the fodder base of the animal husbandry also suffered damage. The sowing of fodder crops was not carried out, so that the acreage of perennial grasses was insignificant, which led to an unsatisfactory state of the land on the basis of liquefaction and contamination of crops. In the left-bank regions of the Ukrainian SSR, liberated in 1943, only $20 \%$ of the areas were sown with fodder crops in comparison with 1940, including perennial grasses - 31\%, annual grasses $-13.9 \%$, root crops $-10.1 \%$. The situation was also complicated by the complete destruction of seed production of fodder $\mathrm{crops}^{25}$.

The reconstruction of the Ukrainian agriculture began in winter 1943 immediately after the liberation of some of its territories. Party and state authorities were guided by the resolution of the Council of People's Commissars of the Ukrainian SSR and the Central Committee of Communist Party "On measures of restoration and reconstruction of agricultural machines and tractors stations and collective farms in areas liberated from Nazi invaders" from January 23, 1943. According to this resolution, local party and Soviet authorities were obliged to restore the work of the district agricultural departments and direct their efforts to the restoration of collective farms and the organization of agricultural work. They also collected and made stocktaking of all collective farm property and inventory, registered all working and productive cattle, allocated it on farms, and provided proper care.

The task of restoring agricultural production and eliminating the negative consequences of the violation and destruction of experiments was set to scientific and research institutions in order to overcome the consequences of German invasive management in the Ukrainian SSR.

${ }^{25}$ Verhunov, V. A. (red.). (2012). Sil's'ke hospodarstvo URSR ta yoho naukove zabezpechennya u 1940-1946 rokakh: zb. dok. i materialiv. [USSR agriculture and its scientific support in 1940-1946: coll. dock. and materials.] NAAN, DNS·HB, TSDAVO Ukrayiny. Kyyiv: Nilan-LTD. P. 10. 
It particularly referred to the experimental stations organized in Ukrainian SSR collective farms, the quantity of which decreased by six times: from 42 in 1941 to 7 in $1944 .^{26}$ Also it was crucial to breed elite and to reproduce the seeds of high-yielding grades of grain, vegetable cultures and long-term legumes ${ }^{27}$.

According to the resolution of the Council of People's Commissars of the Ukrainian SSR "On the state plan of the Ukrainian SSR agriculture in 1945 ", an important measure to ensure planned crops planting was their allocation in the fields of crop rotation taking into account the effective predecessors, while avoiding overload of technical and arable crops of farm fields ${ }^{28}$. In the third chapter of this resolution "On measures to increase yields", special attention was focused on the rapid restoration of crop rotations destroyed by the German invaders, as well as their further effective implementation in the collective farms of the Ukrainian SSR. The restoration of margins of the arable fields and removing boundary marks, making and specifying the plan of transition to scientifically proved agrotechnical actions became very crucial in 1945.

According to this resolution, in the spring of 1945, crops allocation and fallow fields were carried out in accordance with the adopted crops alteration/rotation for effective soil cultivation through crop rotations. Restoration and introduction of crop rotations were carried out primarily in district seed farms, district seed nurseries for perennial grasses and collective farms with large livestock farms, which lacked forage lands $\mathrm{s}^{29}$. They also established seed-breeding plots for legumes

26 (1946). Spravka o sostoyanyy roboty Ukraynskoho nauchno-yssledovatel'skoho ynstytuta zernovoho khozyaystva ym. V.V. Kuybysheva za 1946 h. [Information on the status of robots of the Ukrainian Grain Research Institute named by V.V. Kuibyshev for 1946] TSDAVO Ukrayiny. F. 27. Op. 17. Spr. 40. Ark. 387.

27 (1945). Merezha naukovo-doslidnykh ustanov NKZS URSR za 1945 r. [Network of Research Institutes of the NKVD of the USSR for 1945] TSDAVO Ukrayiny. F. 27. Op. 17. Spr. 1728. Ark. 144.

${ }^{28}$ Perekhrest, O. H. (2011). Sil's'ke hospodarstvo Ukrayiny v 1943-1945 rr.: problemy ta rezul'taty vidbudovy. Ukrayina $v$ druhiy svitoviy viyni: pohlyad $z$ XXI st.: istorychni narysy. [Agriculture of Ukraine in 1943-1945: Problems and results of reconstruction. Ukraine in the Second World War: A View from the 21st Century: Historical Essays] Kyyiv: Naukova dumka. P. 563.

29 (1945). Postanovy RNK URSR i TSK KP(b)U shchodo diyal'nosti naukovodoslidnykh ustanov u 1945 r. [Resolutions of the RNA of the USSR and the Central Committee of the Communist Party of Ukraine (b) U concerning the activities of research institutions in 1945] TSDAVO Ukrayiny. F. 27. Op. 17. Spr. 49. Ark. 133. 
and biennial cereal grasses on at least $1 \%$ of the arable land to enable the collective farms to sow the field of perennial legumes seeds with their own seeds within the following 2-3 years. The resolution of the Council of People's Commissars of the Ukrainian SSR "On measures of improvement the introduction and development of crop rotations in collective farms" of June 21, 1945 was of great significance ${ }^{30}$.

In 1943, using imported from Bashkiria, Kuibyshev, Ulyanovsk and other regions seeds of elite varieties of vegetable crops, scientists grew and harvested 210 tons of seed material of these crops, which together with the return of 52 tons of elite and improved seeds of Ukrainian varieties, evacuated in 1941, provided the formation of seed-breeding plots on the area of 12, 627 hectares in the liberated territories in $1944^{31}$. Exported from the Ukrainian SSR elite seeds, preserved and reproduced in the remote areas of the Ukrainian SSR, provided a rapid recovery of seed vegetable crops. 264 varieties out of 287 existing in the Ukrainian SSR before the World War II, were reproduced in 1946. In these years, the area of seedbreeding plots of vegetable and melon crops grew rapidly.

The lack of the necessary laboratory equipment was a problem that prevented the extension of scientific and research work during 1943-1945. In pre-war time, the separate organizations provided experimental process with laboratory glass, chemical reagents, filter paper, analytical and technical scales, microscopes, calorimeters, psychrometers, thermometers usual and ground, etc. ${ }^{32}$ These material resources were severely destroyed during the occupation and only a small amount of them, evacuated to the Eastern regions of the Ukrainian SSR, returned to the scientific staff of the scientific and research institutions and experimental stations; nevertheless, this number was extremely insufficient.

30 (1948). Vazhneyshye reshenyya po sel'skomu khozyaystvu za 1938-1946 rr. [The most important decisions on agriculture for 1938-1946] Moskva: Sel'khozgyz. P. 390.

31 Verhunov, V. A. (red.). (2012). Sil's'ke hospodarstvo URSR ta yoho naukove zabezpechennya u 1940-1946 rokakh: zb. dok. i materialiv. [USSR agriculture and its scientific support in 1940-1946: coll. dock. and materials.] NAAN, DNS·HB, TSDAVO Ukrayiny. Kyyiv: Nilan-LTD. P. 19.

${ }^{32}$ Verhunov, V. A. (red.). (2012). Sil's'ke hospodarstvo URSR ta yoho naukove zabezpechennya u 1940-1946 rokakh: zb. dok. i materialiv. [USSR agriculture and its scientific support in 1940-1946: coll. dock. and materials.] NAAN, DNS·HB, TSDAVO Ukrayiny. Kyyiv: Nilan-LTD. P. 26. 
The researchers also focused on regional and district meetings on the effective agricultural production. They consulted collective and state farms on appropriate organization of the territory of management ${ }^{33}$. Moreover, they provided collective and state farms with varietal seeds, prepared specialists in agriculture, assisted in organization of field work ${ }^{34}$.

The researchers from scientific institutions systematically visited the rural areas, where they instructed foremen and section leaders, developed schemes of transitional crop rotations, organized work on the destruction of pests in the fields ${ }^{35}$. The implementation of the aforementioned measures ensured the successful implementation of spring sowing of agricultural crops in 1944. Collective farms of the Ukrainian SSR sowed 8 million hectares of arable land, and by the end of spring they fulfilled the plan of planting spring crops by $117 \%$, sugar beet - by $106 \%$, sunflower - by $119 \%$. Collective fams of Dnipropetrovsk region sowed more than 110.4 thousand hectares of spring crops, Kyiv region -84 thousand hectares, Kamenets-Podilskiy region - 30 thousand hectares. The development of pre-war acreage of crops was effectively carried out. In particular, in 1944 the total sown area of agricultural crops in the Ukrainian SSR reached $71 \%$ of the prewar size, grain crops $-80 \%$. In $1945,76 \%$ of the pre-war total acreage of agricultural crops was sown, $84 \%$ of grain crops, $125 \%$ of sunflower, $121 \%$ of millet.

The land management was a crucial component of the restoration process in agriculture. Particularly, the restoration and stocktaking of the land documentation, which was $97.2 \%$ destroyed in collective farms

33 (1944). Informatsiya RNK URSR i TSK KP(b)U pro zabezpechennya nasinnym materialom dlya posivu ovochiv ta tekhnichnykh kul'tur u $1944 \mathrm{r}$. [Information of the RNK of the USSR and the Central Committee of the Communist Party (b) U on the provision of seed material for sowing vegetables and industrial crops in 1944] TSDAVO Ukrayiny. F. 27. Op. 17. Spr. 43. Ark. 76.

34 Kalachykov, O. T. (1945). Dosyahnennya y zavdannya naukovo-doslidnykh zakladiv Narkomzemu Ukrayiny . [and tasks of the National Research Commissions of Ukraine.] Sil's 'ke hospodarstvo Ukrayiny. 1. P. 60.

35 (1946). Spravka o sostoyanyy roboty Ukraynskoho nauchno-yssledovatel'skoho ynstytuta zernovoho khozyaystva ym. V.V. Kuybysheva za 1946 h. [Information on the status of robots of the Ukrainian Grain Research Institute named by V. V. Kuibyshev for 1946] TSDAVO Ukrayiny. F. 27. Op. 17. Spr. 40. Ark. 359. 
during the occupation, was of great importance. Considerable attention was paid to the transfer of land documentation to the land users, bringing to the state-established standards of land usage of collective farms and farmers, as well as workers and employees who lived in rural areas, updating and implementing the correct organization of the territory in collective and state farms ${ }^{36}$.

The restoration of crop rotations in the collective farms of all liberated regions of the Ukrainian SSR was rapidly carried out. By the end of 1943, crop rotations had been restored in 10145 collective farms in the left-bank regions. At the beginning of 1944, their number was $15945^{37}$, at the beginning of 1945 it reached 26487 collective farms $^{38}$ and 705 state farms $^{39}$, although many of them did not have the necessary resource base, draught animals, qualified staff members and a sufficient number of workers ${ }^{40}$.

One of the most important tasks in the process of restoration of agriculture of the Ukrainian SSR was the restoration of pre-war acreage. First of all, cultivated areas of grain, vegetable crops, potatoes, sunflowers were restored, namely, those crops, the cultivation of which enabled to solve the food problem in the country. Despite the implementation of extensive agrotechnical measures, aimed at restoring

36 (1946). Postanovy Rady Ministriv URSR shchodo diyal'nosti naukovodoslidnykh ustanov u 1946 r. [Resolutions of the Council of Ministers of the USSR on the Activity of Research Institutions in 1946] TSDAVO Ukrayiny. F. R-2. Op. 7. Spr. 3353. Ark. 4, 16.

37 (1944). Materialy sesiyi Verkhovnoyi Rady URSR z pytannya «Cherhovi zadachi vidnovlennya sil's'koho hospodarstva URSR» u 1944 r. [Materials of the session of the Verkhovna Rada of the USSR on the issue "Regular tasks of restoration of agriculture of the USSR" in 1944] TSDAHO Ukrayiny. F. 1. Op. 30. Spr. 62. Ark. 130.

38 (1946). Materialy z vidrodzhennya naukovo-doslidnoyi roboty Myronivs'koyi derzhavnoyi selektsiynoyi stantsiyi za 1944-1946 rr. [Materials on the revival of the research work of the Mironov state breeding station for 1944-1946.] TSDAVO Ukrayiny. F. R-27. Op. 17. Spr. 5556. Ark. 21.

${ }^{39}$ (1945). Korotkyy dovidnyk sektora informatsiyi upravlinnya spravamy RNK URSR z osnovnykh pokaznykiv narodnoho hospodarstva URSR u 1945 r. [Brief reference book of the information sector of the RNA management of the USSR RNA on the main indicators of the Ukrainian economy of the USSR in 1945.] TSDAHO Ukrayiny. F. 1. Op. 23. Spr. 3987. Ark. 109.

${ }^{40}$ Vidomosti pro nayavnist' i stan traktoriv v URSR u 1942-1943 rr. [Information on the presence and condition of tractors in the USSR in 1942-1943.] TSDAVO Ukrayiny. F. R-27. Op. 18. Spr. 6. Ark. 16. 
the acreage during the period of reconstruction, its total territories comprised only 20,932 thousand hectares in 1944, in other words $69.2 \%$ of the pre-war area. The sown area of grain and leguminous crops was 15775 thousand hectares or $61.1 \%$, sunflower 852 thousand hectares or $120 \%$, potatoes -1738 thousand hectares or $85.9 \%$, vegetables - 417 thousand hectares or $87.4 \%$, sugar beet 287 thousand hectares or $31.6 \%{ }^{41}$.

The plan for the development of arable land in the Ukrainian SSR (1944) was carried out by collective farms at $104 \%$. State farms reclaimed 711 thousand hectares or $71 \%$ of the pre-war total acreage of crops. In 1945, the overall area of sowing increased by 1.9 million hectares in comparison with 1944. In 1945, in general, the Ukrainian SSR reclaimed $76 \%$ of the pre-war total sown area of crops. The sown area of grain reached $84 \%$ of the pre-war level, sunflower $-125 \%$, millet $-121 \%$. In 1945, owing to the achievements of scientific and research institutions, Ukrainian villages provided the state with more than 12 million tons of grain; almost 3 million tons of winter wheat and spring barley; 2.5 million tons of winter rye and 1.3 million tons of oats ${ }^{42}$.

The scientific and research institutions of animal husbandry improved breed and economic quality of cattle, types of pigs, coarse-woolen and metis sheep to meet the requirements of the resolution of the Central Committee of Communist Party and the Council of People's Commissars of the Ukrainian SSR № 572 "On the state development of animal husbandry in collective and state farms in the Ukrainian SSR in 1945", dated April 19, $1945^{43}$. Scientists carried out breeding work for sheep,

41 (1945). Korotkyy dovidnyk sektora informatsiyi upravlinnya spravamy RNK URSR z osnovnykh pokaznykiv narodnoho hospodarstva URSR u 1945 r. [Brief reference book of the information sector of the RNA management of the USSR RNA on the main indicators of the Ukrainian economy of the USSR in 1945.] TSDAHO Ukrayiny. F. 1. Op. 23. Spr. 3987. Ark. 49, 119.

${ }^{42}$ Perekhrest, O. H. (2011). Sil's'ke hospodarstvo Ukrayiny v 1943-1945 rr.: problemy ta rezul'taty vidbudovy. Ukrayina $v$ druhiy svitoviy viyni: pohlyad z XXI st.: istorychni narysy. [Agriculture of Ukraine in 1943-1945: Problems and results of reconstruction. Ukraine in the Second World War: A View from the 21st Century: Historical Essays] Kyyiv: Naukova dumka. P. 573.

${ }^{43}$ Verhunov, V. A. (red.). (2012). Sil's'ke hospodarstvo URSR ta yoho naukove zabezpechennya u 1940-1946 rokakh: zb. dok. i materialiv. [USSR agriculture and its scientific support in 1940-1946: coll. dock. and materials.] NAAN, DNS·HB, TSDAVO Ukrayiny. Kyyiv: Nilan-LTD. P. 26. 
rabbit and fish farming, established breeding resources of horses in the main regions of the Ukrainian SSR. The scientists identified the methods of accelerated apicultural breeding with high productivity of honey and wax, analyzed the maturity of honey on its physical properties. All these achievements played an important role for the development of animal husbandry in the Ukrainian SSR during the period of reconstruction.

In the early 1947, after the reconstruction of institutions, experimental stations and fields, the network of agricultural research institutions in the Ukrainian SSR consisted of 129 units in comparison with 165 research institutions in 1938. To them belonged 17 research institutes, 52 experimental stations, branches and laboratories, 60 scientific fields and experimental stations ${ }^{44}$. In the postwar period, scientists succeeded in the development of agricultural science, for instance: improving the culture of farming and assisting agricultural authorities, collective farms and state farms in the introduction of scientific achievements and best practices, developing of measures to increase crop and livestock productivity ${ }^{45}$.

In the period of reconstruction, scientists developed methods of soil fertilization to increase the sugar content of beets and rubber in Kok-sagizi with the assistance of the Department of Agricultural Sciences of the Academy of Sciences of the Ukrainian SSR. The system of potash feeding Kok-sagizu was recommended by scientists and provided an increase in the yield of this crop depending on the properties of the soil by $11-42 \%$, seed productivity of leached soils by $40 \%{ }^{46}$. Owing to the introduction of a new fertilizer system, the yield of

44 (1945). Zvit NKZS URSR pro vyrobnychu diyal'nist' i pro khid evakuatsiyi mayna MT·S, kolhospiv ta inshykh sil's'kohospodars'kykh orhanizatsiy NKZS URSR $\mathrm{u}$ period Velykoyi vitchyznyanoyi viyny 1941-1945 rr. [Report of the NKZS of the Ukrainian SSR on the production activity and the course of evacuation of property of MTS, collective farms and other agricultural organizations of the NKZS of the Ukrainian SSR during the Great Patriotic War of 1941-1945.] TSDAVO Ukrayiny. F. 27. Op. 17. Spr. 24. Ark. 17.

${ }^{45}$ Pshenychnyy, N. I. (1972). Do istoriyi rozvytku sil's'kohospodars'koyi nauky i doslidnoyi spravy na Ukrayini. [On the history of agricultural science and research in Ukraine.] Visnyk sil's 'kohospodars 'koyi nauky. 12. P. 42.

${ }^{46}$ Verhunov, V. A. (red.). (2012). Sil's'ke hospodarstvo URSR ta yoho naukove zabezpechennya u 1940-1946 rokakh: zb. dok. i materialiv. [USSR agriculture and its scientific support in 1940-1946: coll. dock. and materials.] NAAN, DNS·HB, TSDAVO Ukrayiny. Kyyiv: Nilan-LTD. P. 28. 
rubber per unit area, depending on the fertility and edaphic soil properties, increased by $31-71 \%$, and the content of rubber in the roots of Kok-sagizu - 1.7-2.0\%. Potash feed was also used in the cultivation of sugar beets, so that extremely high yields were received in the collective and state farms in the first year of their cultivation. Viral diseases of plants, physiology of sick plants and their immunity were under scrutiny, the factors leading to the decrease of clover seeds productivity were found out ${ }^{47}$. However, the search for effective measures to increase the productivity of crops and livestock was not extended by the Department of Agricultural Sciences of the Ukrainian SSR due to the imperfections of the organizational structure of the Academy of Sciences of the Ukrainian SSR. Along with the significant achievements of the Department of Agricultural Sciences of the Ukrainian SSR, some shortcomings can be pointed out: the lack of systematic connections with the departments of agricultural promotion and propaganda of the Ministry of Agriculture of the Ukrainian SSR on the problems of implementation of science achievements in production, lack of resource provision at pilot farms, the lack of specific industrial institutions in the Ukrainian SSR, etc.

\section{CONCLUSION}

Taking into consideration all mentioned above we can come to the following conclusion. During 1943-1945, the scientists of Ukrainian SSR scientific and research institutions solved significant problems of organizational and economic consolidation of research institutes, experimental stations and fields, and those concerning prospective development of agricultural experimental industry in the country. Scientists paid great attention to improving the assistance of collective and state farms of the Ukrainian SSR in eliminating the consequences of fascist invasive barbaric management. In the sphere of agriculture and crop production, the scientists of research institutions developed appropriate agro-technical measures for the further reconstruction of grain and beet farms, in particular, implemented scientifically substantiated grain and beet crop rotations as the basis of effective agriculture. Besides, effective soil treatment and application of organic

47 (1948). Vazhneyshye reshenyya po sel'skomu khozyaystvu za 1938-1946 rr. [The most important decisions on agriculture for 1938-1946] Moskva: Sel'khozgyz. P. 50. 
and mineral fertilizers were also in the focus of attention. A powerful forage base was created in collective farms for further reconstruction of animal husbandry. In this sphere, the scientists of scientific and research institutions aimed their work at the study of measures to improve meadows and pastures, the implementation of productive grass mixtures in field and fodder crop rotations in the production.

\section{SUMMARY}

The article states, that during the period of reconstruction (1943-1945), the state regulation of conducting agricultural scientific researche was managed by the following scientific and methodological centres: the People's Commissariat of agriculture of the Ukrainian SSR and the People's Commissariat of agriculture of food industry of Ukrainian SSR. From 1945, the problems of scientific support of agricultural production were also solved by scientists of the Department of Agricultural Sciences of the Academy of Sciences of the Ukrainian SSR.

It is pointed out that the coordination activity of the Sector of scientific and research institutions of the People's Commissariat of Agriculture of the Ukrainian SSR played a vital role in the development and production process of agriculture of the Ukrainian SSR. Wellknown scientific and research institutions that solved important problems to eliminate the consequences of barbaric management of the Nazi invaders, as well as organizational, economic and scientific development of research institutes, stations and fields that performed research in various fields subordinated to the People's Commissariat of Agriculture of the Ukrainian SSR. Significant amount of work of scientific and research institutions was done in the following areas: agriculture and crop production, selection and seed crops, agronomic melioration and mechanization of agriculture, fruit growing, viticulture and winemaking, as well as animal husbandry.

\section{REFERENCES}

1. Torzecki, R. (1994) Die Rolle der Zusammenarbeit mit der deutschen Be-satzungsmacht in der Ukraine für deren Okkupationspolitik [The role of cooperation with the German representative power in Ukraine for its occupation policy] Europa unterm Hakenkreuz. Okkupation und Kollaboration 1938-1945, 
Achtbändige Dokumentenedition. [Europe under the swastika. Occupation and collaboration 1938-1945, eight-volume document edition] Bd. 1, Berlin/Heidelberg, S. 239-273 (in German)

2. Torzecki, R. (1993). Polacy I Ukraincy. Sprawa ukrainska w czasie II wojny swiatowej na terenie II Rzeczypospolitej.[Poles and Ukrainians. The Ukrainian case during World War II in the territory of the Second Polish Republic] Warszawa: Wydawnictwo naukowe PWN. 349 s. (in Polish)

3. . (1948). Vazhneyshye reshenyya po sel'skomu khozyaystvu za 1938-1946 rr. [The most important decisions on agriculture for 1938-1946] Moskva: Sel'khozgyz. 460 s (in Russian)

4. Verhunov, V. A. (2012). Sil's 'kohospodars'ka doslidna sprava $v$ Ukrayini vid zarodzhennya do akademichnoho isnuvannya: orhanizatsiynyy aspekt. [Agricultural research in Ukraine from birth to academic existence: an organizational aspect.] Kyyiv: Ahrarna nauka. 416 s. (in Ukrainian)

5. Verhunov, V. A. (red.). (2012). Sil's 'ke hospodarstvo URSR ta yoho naukove zabezpechennya u 1940-1946 rokakh: zb. dok. $i$ materialiv. [USSR agriculture and its scientific support in 1940-1946: coll. dock. and materials.] NAAN, DNS·HB, TSDAVO Ukrayiny. Kyyiv: Nilan-LTD. 756 s. (in Ukrainian)

6. Verhunov, V. A. \& Khyzhnyak, V. P. (2004). Ukrayins'ki naukovo-doslidni sil's'kohospodars'ki zaklady $\mathrm{V}$ roky Velykoyi Vitchyznyanoyi viyny. [Ukrainian agricultural research institutions during the Great Patriotic War.] Istorychni zapysky: zbirnyk naukovykh prats'. 1. S. 19-25.

7. Vidomosti pro nayavnist' i stan traktoriv v URSR u 1942-1943 rr. [Information on the presence and condition of tractors in the USSR in 1942-1943.] TSDAVO Ukrayiny. F. R-27. Op. 18. Spr. 6. Ark. 16.

8. Vlasenko, S. (2010). Naslidky nimets'koyi okupatsiyi dlya sil's 'koho hospodarstva viys'kovoyi zony Ukrayiny (za dokumentamy derzhavnykh arkhiviv Ukrayiny). [Consequences of German occupation for agriculture of the military zone of Ukraine (according to documents of the state archives of Ukraine)] Kyyiv. 110 s. (in Ukrainian)

9. (1944). Dodatok do Nakazu № 1147 NKZS URSR pro vidnovlennya ta stan roboty naukovo-doslidnykh ustanov za 1944 r. [Addendum to the Order \# 1147 of the NKVD of the USSR on the 
restoration and state of operation of research institutions for 1944] TSDAVO Ukrayiny. F. 27. Op. 17. Spr. 1053. Ark. 292-293.

10. (1945). Dopovidni zapysky i dovidky pro rezul'taty perevirky spivrobitnykamy NKZS URSR stanu tvarynnytstva $\mathrm{v}$ kolhospakh URSR (za oblastyamy) u 1945 r. [Additional notes and certificates on the results of the examination of the stock-raising of the livestock in the collective farms of the Ukrainian SSR (by oblasts) in 1945] TSDAVO Ukrayiny. F. R-27. Op. 17. Spr. 8886. Ark. 6.

11. (1945). Dopovid' Narkoma zemlerobstva URSR H.P. Butenka na Pershomu respublikans'komu zasidanni peredovykiv produktyvnoho tvarynnytstva i konyarstva kolhospiv URSR vid 24-27 hrudnya 1945 r. [Report of the People's Commissar of Agriculture of the Ukrainian SSR GP Butenko at the First Republican Meeting of the Leaders of Productive Livestock and Horse Breeding of the Collective Farms of the USSR from December 24-27, 1945.] TSDAVO Ukrayiny. F. R-27. Op. 17. Spr. 8882. Ark. 7-8.

12. (1945). Zvit NKZS URSR pro vyrobnychu diyal'nist' i pro khid evakuatsiyi mayna MT.S, kolhospiv ta inshykh sil's'kohospodars'kykh orhanizatsiy NKZS URSR u period Velykoyi vitchyznyanoyi viyny 1941-1945 rr. [Report of the NKZS of the Ukrainian SSR on the production activity and the course of evacuation of property of MTS, collective farms and other agricultural organizations of the NKZS of the Ukrainian SSR during the Great Patriotic War of 1941-1945.] TSDAVO Ukrayiny. F. 27. Op. 17. Spr. 24. Ark. 4-58.

13. Zubets', M. V. (red.). (2008). Viddil sil's'kohospodars 'kykh nauk Natsional'noyi akademiyi nauk Ukrayiny (1945-1956): zb. dok. $i$ materialiv. [Department of Agricultural Sciences of the National Academy of Sciences of Ukraine (1945-1956): Coll. dock. and materials]. UAAN, DNS·HB UAAN, NAN Ukrayiny, NBU im. V. I. Vernads'koho. Kyyiv: Ahrarna nauka. 400 s.

14. (1944). Informatsiya RNK URSR i TSK KP(b)U pro zabezpechennya nasinnym materialom dlya posivu ovochiv ta tekhnichnykh kul'tur u 1944 r. [Information of the RNK of the USSR and the Central Committee of the Communist Party (b) U on the provision of seed material for sowing vegetables and industrial crops in 1944] TSDAVO Ukrayiny. F. 27. Op. 17. Spr. 43. Ark. 76. 
15. Kalachykov, O. T. (1945). Dosyahnennya y zavdannya naukovo-doslidnykh zakladiv Narkomzemu Ukrayiny .[and tasks of the National Research Commissions of Ukraine.] Sil's'ke hospodarstvo Ukrayiny. 1. S. 59-61.

16. (1945). Korotkyy dovidnyk sektora informatsiyi upravlinnya spravamy RNK URSR z osnovnykh pokaznykiv narodnoho hospodarstva URSR u $1945 \mathrm{r}$. [Brief reference book of the information sector of the RNA management of the USSR RNA on the main indicators of the Ukrainian economy of the USSR in 1945] TSDAHO Ukrayiny. F. 1. Op. 23. Spr. 3987. Ark. 48-129.

17. (1946). Materialy z vidrodzhennya naukovo-doslidnoyi roboty Myronivs'koyi derzhavnoyi selektsiynoyi stantsiyi za 1944-1946 rr. [Materials on the revival of the research work of the Mironov state breeding station for 1944-1946.] TSDAVO Ukrayiny. F. R-27. Op. 17. Spr. 5556. Ark. 21-22.

18. (1944). Materialy sesiyi Verkhovnoyi Rady URSR z pytannya "Cherhovi zadachi vidnovlennya sil's'koho hospodarstva URSR" u 1944 r. [Materials of the session of the Verkhovna Rada of the USSR on the issue "Regular tasks of restoration of agriculture of the USSR" in 1944] TSDAHO Ukrayiny. F. 1. Op. 30. Spr. 62. Ark. 109-246.

19. (1945). Merezha naukovo-doslidnykh ustanov NKZS URSR za 1945 r. [Network of Research Institutes of the NKVD of the USSR for 1945] TSDAVO Ukrayiny. F. 27. Op. 17. Spr. 1728. Ark. 144-146.

20. Ovsiyenko, A. M. (2010). Osoblyvosti finansovoyi systemy Ukrayins'koyi RSR u vidbudovchyy period (druha polovyna 40-kh pochatok 50-kh rokiv XX st.). [Features of the financial system of the Ukrainian SSR in the reconstruction period (the second half of the $1940 \mathrm{~s}$ - the beginning of the 1950s).] Kyyiv. 56 s. (in Ukrainian)

21. Perekhrest, O. H. (2011). Sil's'ke hospodarstvo Ukrayiny $v$ 1943-1945 rr.: problemy ta rezul'taty vidbudovy. Ukrayina $v$ druhiy svitoviy viyni: pohlyad $z$ XXI st.: istorychni narysy. [Agriculture of Ukraine in 1943-1945: Problems and results of reconstruction. Ukraine in the Second World War: A View from the 21st Century: Historical Essays] Kyyiv: Naukova dumka. S. 563-615. (in Ukrainian)

22. (1945). Postanovy RNK URSR i TSK KP(b)U shchodo diyal'nosti naukovo-doslidnykh ustanov u 1945 r. [Resolutions of the RNA of the USSR and the Central Committee of the Communist Party 
of Ukraine (b) U concerning the activities of research institutions in 1945] TSDAVO Ukrayiny. F. 27. Op. 17. Spr. 49. Ark. 128-139.

23. (1946). Postanovy Rady Ministriv URSR shchodo diyal'nosti naukovo-doslidnykh ustanov u 1946 r. [Resolutions of the Council of Ministers of the USSR on the Activity of Research Institutions in 1946] TSDAVO Ukrayiny. F. R-2. Op. 7. Spr. 3353. Ark. 4-16.

24. Pshenychnyy, N. I. (1972). Do istoriyi rozvytku sil's'kohospodars'koyi nauky i doslidnoyi spravy na Ukrayini. [On the history of agricultural science and research in Ukraine.] Visnyk sil's 'kohospodars'koyi nauky. 12. S. 38-46.

25. (1946). Spravka o sostoyanyy roboty Ukraynskoho nauchnoyssledovatel'skoho ynstytuta zernovoho khozyaystva ym. V.V. Kuybysheva za $1946 \mathrm{~h}$. [Information on the status of robots of the Ukrainian Grain Research Institute named by V.V. Kuibyshev for 1946] TSDAVO Ukrayiny. F. 27. Op. 17. Spr. 40. Ark. 247-406.

26. (1975). Ukraynskaya SSR v Velykoy Otechestvennoy voyne Sovetskoho Soyuza 1941-1945 rr. [The Ukrainian SSR in the Great Patriotic War of the Soviet Union 1941-1945.] V 3-kh t. T. 3. Kyev: Polytyzdat. 565 s. (in Russian)

\section{Information about the author: Olena Korzun,}

Candidate of Historical Sciences, Doctoral student of the National Scientific Agricultural Library of National Academy of Agrarian Sciences of Ukraine, 10, Geroiv Oborony str., Kyiv, 03127, Ukraine ORCID ID: orcid.org/0000-0003-2869-9549 